\title{
万歩計を利用した慢性血液透析患者の活動量の評価と 運動療法の試み
}

\author{
久松末子前川ミツ子 宮田薰本山真弓 \\ 内田淑子飛永艶子原田篤実白石恒雄 \\ 松山赤十字病院透析センター
}

(昭和 63 年 12 月 27 日受付)

key words : 万歩計, 運動療法, 慢性血液透析

〈要旨〉

慢性外来血液透析患者 47 例について 1 週間万歩計による歩数の調査をおこなった. 1 日の歩数の程度により透析 日, 非透析日とも 3000 歩以下の। 群 13 例, どちらかが 3000 歩以下の川群 11 例, どちらも 3000 歩以上の川I群 23 例 に分けて比較すると, I 群で年齢, 透析歴が有意に大きかった. また, 下剤なしで便通良好な者が川群で有意に多かっ た. 性別, 糖尿病 (DM) の有無, 職業, 体重増加率, Ht, CTR には有意な差は見られなかった。

I 群, II群の中から 16 例を選び歩数の増加を目的とした万歩計による運動療法の指導を 6 か月間行った. 歩数は透 析日が指導前の平均 1852 歩から 3 か月後 2946 歩, 6 か月後 3407 歩へ, 非透析日が指導前の平均 2869 歩から 3 か月 後 4480 歩, 6 か月後 5098 歩へと透析日, 非透析日とも約 2 倍に増加した. 下剂投与量, 水分㩒取量, 体重増加率, Ht, CTR, T. Chol, TG, 血圧に有意な変化は見られなかったが, 体力に自信がついた, 汗が出始めた, 便通が良くなっ たなどの自覚症状の改善と他人と接する機会が多くなったなどの社会生活への適応の拡大が見られた。

\section{Evaluation of life activities and exercise conditioning using a pedometer in chronic hemodialysis patients}

Sueko Hisamatsu, Mitsuko Maekawa, Kaoru Miyata, Mayumi Motoyama, Toshiko Uchida, Tsuyako Tobinaga, Atsumi Harada, M. D., Tsuneo Shiraishi, M. D.

Dialysis Center, Matsuyama Red Cross Hospital

We evaluated the life activities of chronic hemodialysis patients using a pedometer (Mampo Meter ${ }^{\circledR}$ ). The patients were divided into three groups based on the number of steps a day registered on the pedometer. Group I : 13 patients with fewer than 3000 steps per day on both dialysis and non-dialysis days. Group || : 11 patients with fewer than 3000 steps on either dialysis or non-dialysis days. Group III : 23 patients with over 3000 steps on both dialysis and non-dialysis days.

Patients in Group I were significantly older and had undergone significantly longer periods of hemodialysis treatment than those in the other two groups. There were significantly more patients who passed normal stools regularly and easily without laxatives in Group III than in the other two groups. No significant differences were noted with respect to sex, original disease, occupation, body weight gain between successive dialysis, Ht and CTR.

Sixteen patients were selected from group I and II for excercise conditioning using a pedometer. Each patient was given a goal of daily steps by his/her nurse every week, and the actual steps were checked and recorded. After 3 and 6 months of 'exersise conditioning, daily steps had increased from $1852 \pm 1018$ (mean \pm SD) to 2946士 1280 and $3407 \pm 1156$ on dialysis days, and from $2869 \pm 1590$ to $4480 \pm 1940$ and $5098 \pm 2762$ on non-dialysis days. Although there were no significant changes in the dose of laxatives, degree of water intake, body weight gain between successive dialysis, Ht, CTR, T. Chol, TG or blood pressure after the course, beneficial effects on physical

久松 末子 松山赤十字病院透析センター

厂790 松山市文京町 1 番 (0899-24-1111) and emotional status such as regained confidence in physical strength, onset of sweating, improved defeca. 
tion and increased frequency of social contacts with other people were noted in over half of the patients.

\section{はじめに}

近年，慢性血液透析患者の増加と透析療法の進步にと もない, 10 年以上の長期生存例が 12,000 人を越え ${ }^{12}$, 医 学的な延命のみ問題としていた時代から, 患者の生活 の質 (quality of life, QOL) を向上させる事に力をいれ て行かなければならない時代へと移りつつある。慢性血 液透析患者で性，健常人に比べて運動耐容能，心機能の 低下が ${ }^{2,3,10)}$ ，精神的な不安，意欲の欠如とあいまって QOL の向上の防げとなっている

最近, 慢性血液透析患者の運動療法の医学的効用と QOL の向上効果がみられるとの報告がされてきてい $3^{5 \sim 11}$. 我々は, 慢性外来血液透析患者に特別の器具を必 要とせず，生活に取り入れ易い万歩計による運動療法を 試みたので報告する。

\section{対象並びに方法}

1) 万歩計による活動量の調査

慢性外来血液透析患者 47 例について万歩計による 1 日の歩数の調查を 1 週間行い, 性別, 年齢, 透析歴, 職

\section{表 1 1日の歩数の程度による群分類}

$\begin{aligned} \text { I 群 }(\mathrm{n}=13): & 1 \text { 日の歩数が透析日, 非透析日とも } 3,000 \text { 歩以 } \\ & \text { 下の者 } \\ \text { II群 }(\mathrm{n}=11): & \text { 透析日, 非透析日のいずれかが } 3,000 \text { 歩以下の } \\ & \text { 者 } \\ \text { III群 }(\mathrm{n}=24): & \text { 透析日, 非透析日とも } 3,000 \text { 歩以上の者 }\end{aligned}$

表 2 アンゲート調查の項目

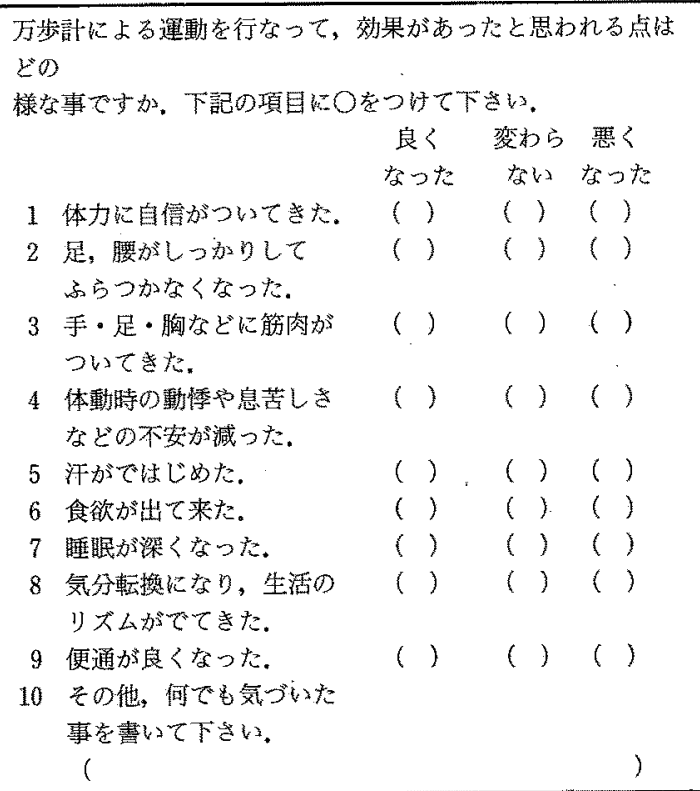

業, 下敵投与量, 体重增加率，ヘマトクリット $(\mathrm{Ht})$, 心 胸比 (CTR) などの因子との関係を検討した。歩数は透 析日，非透析日に分けて検討した。また，1日の歩数の 程度によって表 1 のごとく 3 群に分類し， 3 群間で比較 検討を行った。

2)歩数の少ない I 群，II群の 24 例のうちから医学的 に運動療法が可能て協力が得られた 16 例を対象として, 万歩計による歩数の増加を目的とした運動療法を 6 か月 間指導し，自覚症状，他覚所見に及玨す効果を検傠した。 自覚症状については，3か月，6加月後に表 2 に示すア ンケート調査を行い評価した。他党所見では, 毎月の下 剂投与量, 尿量, 水分㩒取量, 体重增加率, Ht, CTR, T. Chol, $\mathrm{TG}$, 血圧の平均值を求め, その推移を検討した. 結果

\section{1) 万歩計による活動量の評価}

表 3 万歩計による活動量調查の対象症例

\begin{tabular}{|c|c|c|c|}
\hline 対象患者数 & & 47 & \\
\hline 性 別 & & 男 17 & 女 30 \\
\hline 年 齢 & （歳） & $50.7 \pm 14.4$ & $(18 \sim 76)$ \\
\hline 透析歴 & (月) & $40.0 \pm 32.5$ & $(1 \sim 158)$ \\
\hline \multirow[t]{5}{*}{ 職 業 } & & 主 婦 & 20 名 \\
\hline & & 無 職 & 18 \\
\hline & & 会社員 & 5 \\
\hline & & 自営業 & 2 \\
\hline & & 学 生 & 2 \\
\hline \multirow[t]{2}{*}{ 原疾患 } & & DM & 5 \\
\hline & & 非 DM & 42 \\
\hline
\end{tabular}

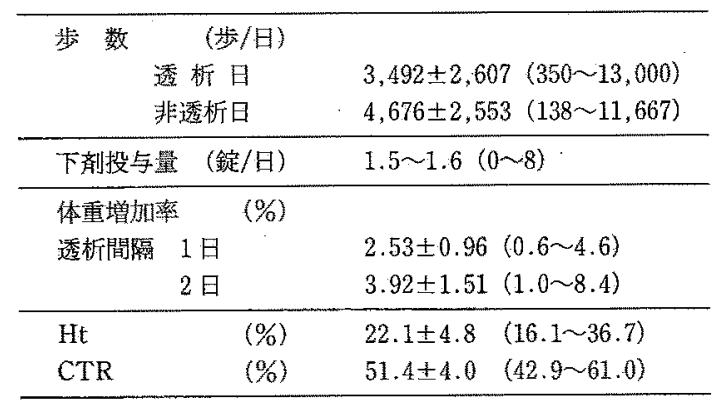

表 4 、職業と歩数との関係

\begin{tabular}{cc|c|c}
\hline & & 透析日の歩数 & 非透析日の歩数 \\
\hline 主 婦 & $\mathrm{n}=20$ & $3,416 \pm 2,518$ & $5,304 \pm 2,481$ \\
無 職 & $\mathrm{n}=18$ & $3,014 \pm 2,402$ & $3,961 \pm 2,473$ \\
会社員 & $\mathrm{n}=5$ & $5,897 \pm 2,925$ & $4,805 \pm 2,367$ \\
自営業 & $\mathrm{n}=2$ & $2,633 \pm 2,200$ & $4,288 \pm 3,188$ \\
学 生 $\mathrm{n}=2$ & $3,400 \pm 950$ & $4,900 \pm 1,900$ \\
\hline
\end{tabular}


表 53 群間の年齢, 尿量, 透析歴, 下剤投与量, Ht, CTR, 体重増加率の比較

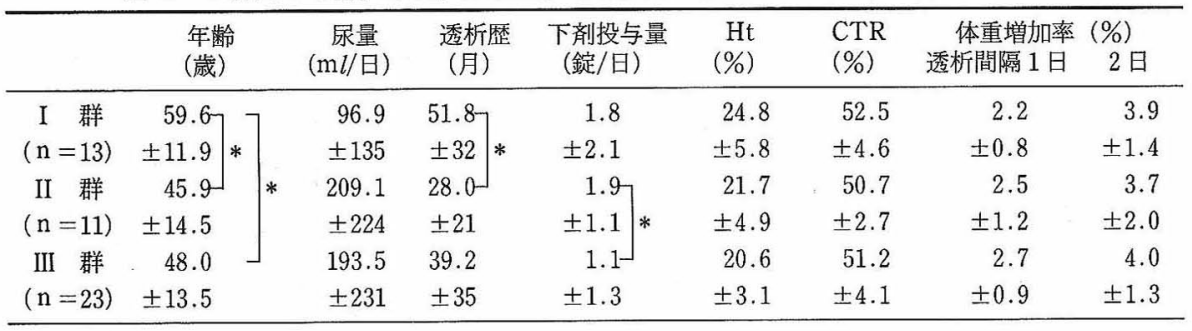

表 6 万歩計による運動療法の対象症例

\begin{tabular}{llll}
\hline 対象患者数 & & \multicolumn{2}{c}{16} \\
\hline 性 別 & & 男 8 名 & 女 8 名 \\
年 齢 & (歳) & $52.2 \pm 15.9$ & $(18 \sim 75)$ \\
透析歴 & (月) & $43.4 \pm 31.3$ & $(1 \sim 125)$ \\
\hline 職 業 & & 主 婦 & 5 名 \\
& & 無 職 & 10 名 \\
& & 自営業 & 1名 \\
\hline 原疾患 & & DM & 4名 \\
& & 非 DM & 12 名 \\
\hline 歩 数 & 透 析 日 & $1,852 \pm 1,018(433 \sim 4,100)$ \\
& 非透析日 & $2,869 \pm 1,591 \quad(138 \sim 6,650)$ \\
\hline
\end{tabular}

万歩計による運動量の調查をおこなった慢性外来血液 透析患者 47 例を表 3 に示す。男 17 例, 女 30 例で年齢は 18 歳より 76 歳, 平均 50.7 歳, 透析歴は 1 か月より 158 か月，平均 40 か月で， 5 例の DM 症例を含んでいる。 全体での歩数は透析日が 350 より 13,000 歩, 平均 3492 歩, 非透析日が 138 歩より 11,667 歩, 平均 4676 歩であっ た。下剤投与量は $1.5 \pm 1.6$ 錠, 体重増加率は透析間隔 1 日 $2.53 \pm 0.96 \% ， 2$ 日 $3.92 \pm 1.51 \%$, Ht は $22.1 \pm$ $4.8 \%$, CTR $51.4 \pm 4.0 \%$ であった。性別で歩数の有 意差は見られなかった。歩数と年齢，透析歷，下剤投与 量, 体重増加率, Ht, CTR の間に相関はみられなかった。 職業との関係では表 4 に示すごとく透析日に会社員が多 く, 非透析日に主婦が多い傾向がみられたが他の職種と 比較して有意差はなかった。しかし前述のごとく歩数の 程度によって 3 群に分け, 他のパラメーターとの関係を 検討すると，歩数のもつとも少ない I 群で他の 2 群より 年齢, 透析歷が有意に大きかった(表 5 )。また， 3 群間 の下剤投与量を比較してみると下郕なしで便通良好なも のが I 群 $31 \%$ ，II群 18\%であるのに対しIII群では $61 \%$ と有意に高率に見られた（図 1)。

2) 万歩計による運動療法の効果

I 群，II群の中で医学的に運動療法が可能で協力が得 られた 16 例を対象として万歩計による歩数の増加を目

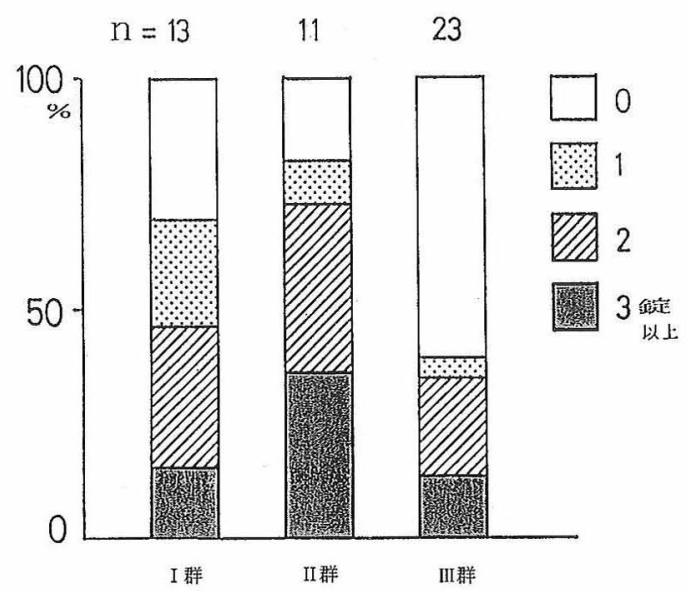

図 13 群間の下剤投与量の比較

的とした運動療法を 1988 年 3 月より 8 月までの 6 か月 間指導し，自覚症状，他覚所見に及ほす効果を検討した。 対象とした 16 例を表 6 亿示す。男 8 例, 女 8 例で 4 例の DM 症例を含んでいる。運動療法の方法は，受持ちナー スが各症例毎に毎週の目標歩数を設定し, 歩数を自己管 理ノートに記載させてチェックする簡単なものである。 目標歩数は透析日, 非透析日に分け, 患者の状態を観察 しながらナースのカンファレンスで決められた。

図 2 に運動療法指導後 6 か月までの歩数の推移を示 す。 2 月より 8 月まで段階的に歩数の増加がみられた。 歩数は指導前の透析日の平均 $1852 \pm 1018$ (平均 \pm SD) 歩, 非透析日の平均 $2869 \pm 1591$ 歩より 3 か月後それぞれ $2946 \pm 1280$ 歩， $4480 \pm 1940$ 歩へ， 6 加月後 $3407 \pm 1156$ 歩, $5098 \pm 2762$ 歩へと約 2 倍に増加した。 6 か月後には 対象 16 例中 12 例が透析日, 非透析日共 1 日 3000 歩以上 に達し、III群へ移行した。

表 7 に他のパラメーターの推移を示す。この間下荗投 与量, 水分提取量, 体重増加率, Ht, CTR, T. Chol, TG, 血圧に有意な変化は見られなかった。

自覚症状の変化を 1988 年 5 月 ( 3 か月後), 8 月 ( 6 か月後）にアンケートにて調查した結果を図 3 , 図 4 に 
表 7 万歩計による運動療法指導後の各種データーの推移

\begin{tabular}{|c|c|c|c|c|c|c|c|c|}
\hline & & 2 月 & 3 月 & 4 月 & 5 月 & 6 月 & 7 月 & 8月 \\
\hline 下剂投与量 & （錠/日） & $1.4 \pm 1.1$ & $1.5 \pm 1.4$ & $1.4 \pm 1.3$ & $1.3 \pm 1.3$ & $1.3 \pm 1.3$ & $1.4 \pm 1.4$ & $1.3 \pm 1.1$ \\
\hline 水分摄取量 & $(\mathrm{m} l /$ 日) & $538 \pm 268$ & $506 \pm 164$ & $497 \pm 186$ & $539 \pm 185$ & $563 \pm 182$ & $559 \pm 202$ & $553 \pm 193$ \\
\hline $\begin{array}{l}\text { 体重増加率 } \\
\text { 透析間隔 } 1 \text { 日 }\end{array}$ & $(\%)$ & $2.1 \pm 0.9$ & $2.7 \pm 1.2$ & $2.4 \pm 1.3$ & $2.1 \pm 1.1$ & $2.2 \pm 1.3$ & $2.2 \pm 1.2$ & $2.4 \pm 1.5$ \\
\hline $\begin{array}{l}\text { 体重増加率 } \\
\text { 透析間隔 } 2 \text { 日 }\end{array}$ & $(\%)$ & $3.7 \pm 1.8$ & $3.9 \pm 1.5$ & $4.2 \pm 1.9$ & $3.9 \pm 2.0$ & $3.9 \pm 2.0$ & $3.3 \pm 1.9$ & $3.6 \pm 2.0$ \\
\hline $\mathrm{Ht}$ & $(\%)$ & $22.0 \pm 5.2$ & $22.5 \pm 5.1$ & $21.6 \pm 4.5$ & $20.8 \pm 3.4$ & $21.2 \pm 3.5$ & $20.6 \pm 3.5$ & $21.5 \pm 4.5$ \\
\hline CTR & $(\%)$ & $52.0 \pm 3.5$ & $52.2 \pm 3.9$ & $52.5 \pm 5.0$ & $53.4 \pm 4.3$ & $52.0 \pm 5.4$ & $52.4 \pm 5.0$ & $51.6 \pm 4.4$ \\
\hline T. chol & $(\mathrm{mg} / \mathrm{d} l)$ & $157 \pm 41$ & $153 \pm 38$ & $154 \pm 44$ & $144 \pm 38$ & $141 \pm 38$ & $146 \pm 40$ & $146 \pm 41$ \\
\hline TG & $(\mathrm{mg} / \mathrm{d} l)$ & $136 \pm 42$ & $157 \pm 72$ & $150 \pm 65$ & $151 \pm 72$ & $164 \pm 57$ & $126 \pm 44$ & $136 \pm 66$ \\
\hline 収縮期血圧 & $(\mathrm{mmHg})$ & $147 \pm 19$ & $154 \pm 20$ & $151 \pm 20$ & $153 \pm 23$ & $149 \pm 21$ & $149 \pm 21$ & $147 \pm 19$ \\
\hline 拡張期血圧 & $(\mathrm{mmHg})$ & $78 \pm 12$ & $77 \pm 10$ & $78 \pm 12$ & $76 \pm 12$ & $76 \pm 9$ & $77 \pm 10$ & $76 \pm 10$ \\
\hline
\end{tabular}

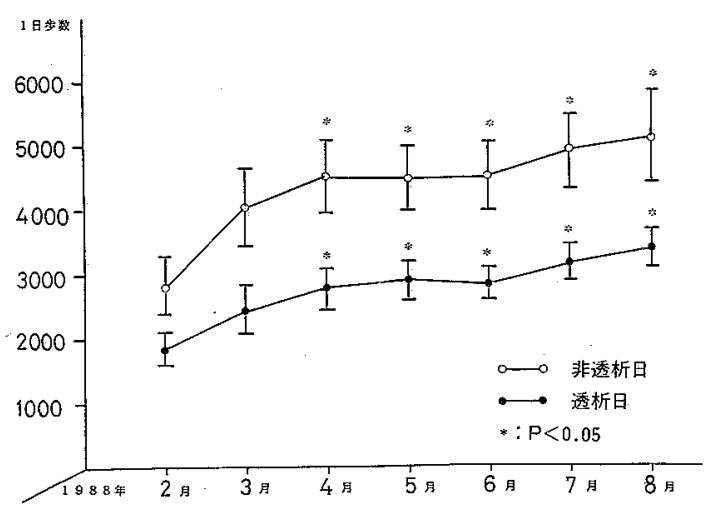

図 2 万歩計による運動療法指導による1 日歩数 の変化 $(\mathrm{n}=16$, 平均 $\pm \mathrm{SD})$

示す。 5 月の調查では，各項目とも悪くなったと言うも のはいなかった。気分転換になり生活にリズムが出てき た，食欲が出てきたは $70 \%$ 以上を示し，体力に自信がつ いた，足腰がしっかりしてきた，睡眠が深くなった，が 約 $50 \%$ を占めた. 汗が出始めたが $40 \%$, 下剂投与量は有 意な減少を示さなかったが便通が良くなったと答えたも のが $40 \%$ に見られた。 6 か月後の 8 月のアンケート調查 では感冒で体調不良の 1 例が 1 部の項目で悪化したと答 えた。気分転換，食欲，体力，是腰のふらつき，睡眠の 項目では良くなったと答えたものが 5 月の時より減少し てみられるが，2月との比較でという質問にもかかわら ず 5 月との比較で答えたものがあったためと考えられ る. 体動時動悸, 息切れがしはなくなった, 汗が出始め た，便通が良くなったの項目では 5 月より更に増加し $60 \% に$ 達した。 その他の意見として，万歩計を着けるこ とにより頑張る気力が出てきた，生活の励みになった， 買物や家事をしても体が楽になった，今まで家に籠りが ちだったが歩くことにより他人と接する機会が多くなっ

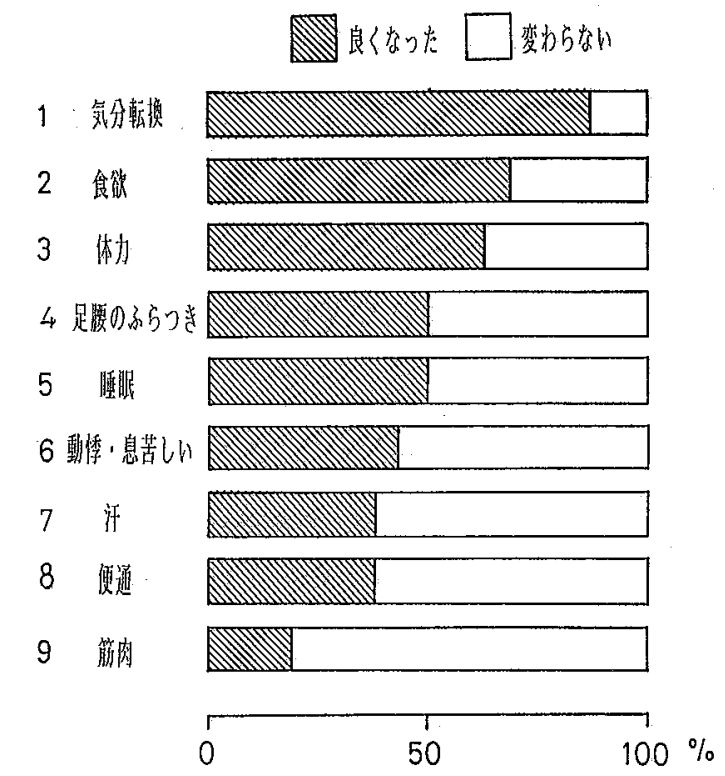

図 3 運動療法指導後 3 か月目（1988 年 5 月）の アンケート結果

たなどの効果が見られた。

\section{考察}

慢性外来血液透析患者で，万歩計を用いて 1 日の歩数 を調查すると, 透析日平均 3492 歩, 非透析日平均 4676 歩 であった。これは一般健常人のデーター，主婦 $4000 \sim 5000$ 歩会社員 $8000 \sim 10000$ 歩に比べて少なく, 透 析患者の日常生活での運動量の低下が同える ${ }^{12)}$.

歩数と他のパラメーターとの関係を見ると，歩数が少 ない I 群で有意に年齢が高く，透析歴が長く，歩数の多 いIII群で下剤に頼らず便通良好な症例が多かった。職種 では主婦が非透析日に，会社員が透析日に歩数が多い傾 向が見られたが有意な差ではなかった。性別，原疾患， 


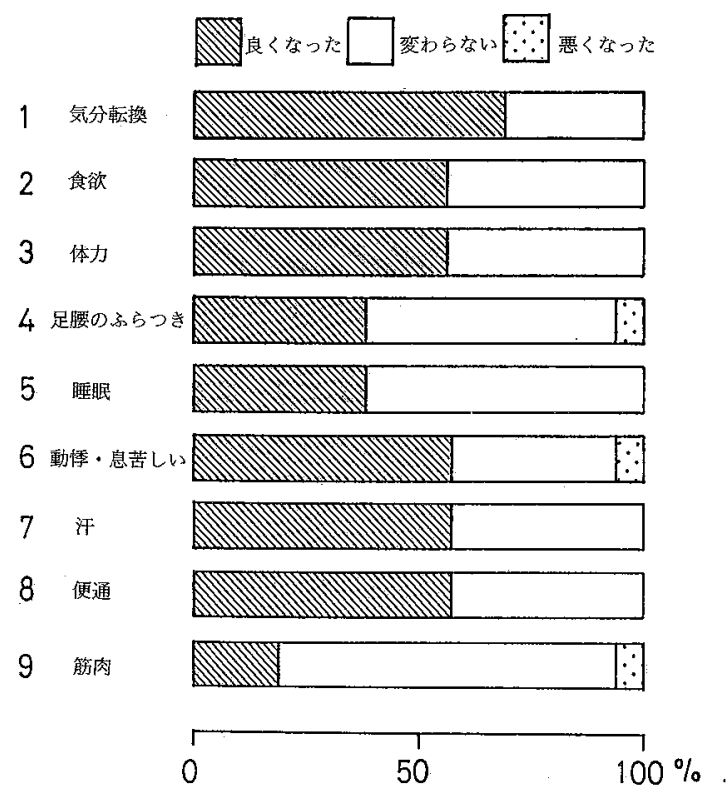

図 4 運動療法指導後 6 か月目（1988 年 8 月）の アンケート結果

$\mathrm{Ht}, \mathrm{CTR}$, 体重増加率, 水分提取量には差がみられなかっ た。

慢性血液透析患者の運動療法の報告ではトレッドミル を使用した運動耐容能の評価と歩行, ジョギングプログ ラムが多い ${ }^{5 \sim 11)}$.しかし特殊な設備がいる事, 非透析日に 患者が来院しなければならない事, 体重増加の多い時に

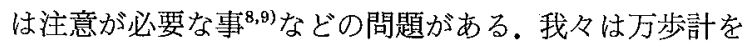
用いて家庭でいつでもできる日常の歩数を増加させるこ とを目的とした運動療法を試みた ${ }^{12)}$.

慢性血液透析患者に対する運動潦法の効果については Goldberg $~^{5,6)}$ が脂質, 糖代謝の改善, 高血圧の改善が見 られると報告し,また心理テストでうつ状態, 不安, 対 人関係の改善がみられたとしている 血圧下降の頻度の減少を, 長谷ら ${ }^{91}$ は運動耐容能の増加 と心血管系の機能低下の改善が見られたと報告してい る.筫血の改善については効果が見られたとする報告

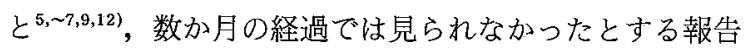
がある ${ }^{8)}$. 緑川ら ${ }^{11}$ は運動療法にて発汗量が増加するが, 体重増加量の減少は見られなかったと報告し, 我々の結 果と一致している! 戸田は ${ }^{12}$ 我々と同様に万歩計を用 いて慢性血液透析症例の肥満の改善を報告している。 我々の症例では 6 か月の運動療法の指導によって体重増 加率, Ht, CTR な゙の良化は見られなかったが, 体力に 対する自信などの心理的な好影響,便通の自覚的な改善, 発汗の出現などの効果が見られた. 今回の万歩計を利用
した運動療法は他の報告にくらべて運動強度, 期間とも 少なく ${ }^{12)}$, 更に歩数を増加させ長期の経過を見る必要が あると考えられた。

\section{結語}

1 ) 慢性外来血液透析患者 47 例について万歩計を用い て活動量を評価し，他の因子との関係を検討した。1日 の歩数の程度によって 3 群に分けて比較すると, 最も少 ない群で年龄, 透析歴が有意に大きく, 最も多い群で下 剤に頼らず便通良好な有意に多かった。

2）1日の歩数が少ない症例の中から 16 例を選び，万 歩計を利用した運動療法を 6 か月間指導した結果, 歩数 は透析日, 非透析日とも指導前の約 2 倍に増加した。

3 ) 6 か月間の観察では下剤投与量, 体重増加率, $\mathrm{Ht}$, CTR, T. Chol, TG, 血圧に変化はみられなかったが, 体 力に自信がついた, 汗が出始めた, 便通が良くなったな どの自覚症状の改善が高頻度に見られた. 更に目標歩数 を増し, 長期の観察を行うことにより自己管理, QOLの 向上を目指す必要があると考えられた。

\section{文献}

1）小高通夫：わが国の慢性透析療法の現況. 第 33 回日 本透析療法学会, 名古屋 1988. 7

2）長谷弘記, 中村良一, 海老根東雄, 赤池 真, 野村 正征, 張 光哲: 慢性血液透析患者の Symptom limited treadmill excercise test による運動耐容能 および心機能評価と運動療法。日腎誌 25 ： 1255-1265，1983

3）長谷弘記, 張 光哲, 中村良一, 玉城 厚, 渡部純 郎, 赤池 真, 露木和夫, 山家俊彦, 海老根東雄, 町井 潔：慢性血液透析患者にお引る運動耐容能, 心機能㧍よび末梢循環機能の非侵襲的評価. 腎と透 析 $18: 649-654,1985$

4）春木繁一：透析患者の quality of life一児童・成人・ 老年患者それぞれの課題一。臨床透析 4: 1339-1346, 1988

5) Goldberg A P, Hagberg J M, Delmez J A, Haynes M E, Harter H R : Metabolic effects of excercise training in hemodialysis patients. Kidney Int 18 : 754-761, 1980

6) Goldberg A P, Hagberg J, DeimezJ A, Carney R M, McKevitt P M, Eshani A A, Harter H R : The metabolic and psychological effects of excercise training in hemodialysis patients. Am J Clin Nutr $33: 1620-1628,1980$

7）山家俊彦, 張 光哲, 赤池 真, 露木和夫, 野村正 征, 長谷弘記, 海老根東雄: 慢性血液透析患者にお 
ける運動療法の効果一血液透析中の血圧低下と自党 症状に関する检討一。日婜誌 $26: 399-406,1984$

8) Zabetakis P M, Gleim GW, Pasternack F L, Saraniti A, Nicholas J A, Michelis M F : Long -duration submaximal excercise conditioning in hemodialysis patients. Clin Nephrol $18: 17-22$, 1982

9) 長谷弘記, 張 光哲: 社会復㝸と運動療法, 医学的 な面加ら. 前田貞亮編, 透析患者の精神・ 心理面の ケア，190-205, 日本メディカルセンター, 1984

10) 長谷弘記, 渡部純郎, 中村良一, 矢吹 壮, 町井 潔, 李美根雄, 海老根東雄, 赤池 真, 露木和夫, 張光
哲: 慢性血液透析患者の運動耐要能, 心機能おるび 末梢循環機能におよぼす運動療法の効果。日腎誌 $27: 1429-1436,1985$

11）緑川博美, 露木和夫, 山家俊彦, 赤池 真, 野村正 征, 長谷弘記, 渡部純郎, 吉川昌男, 海老根東雄, 張 光哲：慢性血液透析患者に対する運動療法の効 果一発汗量に関する検討一, 透析会誌 $20: 333-338$, 1987

12）戸田明美：社会復㷌と運動療法, 実践面汃ら. 前田 貞亮編，透析患者の精神・心理面のゲア，206-211， 日本メディカルセンター, 1984 